\title{
How to distinguish a "scientoskeptic" from a "scientoenthusiast"? Psychometric properties and criteria for qualitative interpretation of the scores of the Views of Science Questionnaire in a Polish quota sample
}

\author{
Łukasz Jach \\ Institute of Psychology, Department of Social Sciences, University of Silesia, Katowice, Poland
}

\section{BACKGROUND}

The main aim of this study was to develop criteria for qualitative interpretation of the scores of the Views of Science Questionnaire (VoSQ), which is a tool for measuring the level of scientistic worldview. Another goal was to verify the psychometric properties of the tool in an adequately large and demographically diverse sample.

PARTICIPANTS AND PROCEDURE

The study involved 1,119 participants aged 18 to 87 who filled in the Polish version of the VoSQ via the Internet. The obtained results were subjected to reliability analysis, confirmatory factor analysis and analyses aimed at developing criteria for the qualitative interpretation of both individual and group scores of the VoSQ scales.

\section{RESULTS}

The CFA analysis showed a satisfactory level of fit of the VoSQ factor structure containing one higher-order factor and four sub-factors. The reliability of the tool scales was also satisfactory. The obtained results showed gender and age differences, but no differences related to the level of education. This information was used to develop the percentile-based criteria for the interpretation of the individual scores and the mean and standard deviation-based criteria for qualitative interpretation of the group scores.

CONCLUSIONS

The relationship between science and its social reception is becoming an increasingly important issue. The development of criteria for the qualitative interpretation of the results of the Views of Science Questionnaire makes it possible to use it as a tool for diagnosing attitudes towards science, displayed by both individuals and groups. This knowledge may be useful in improving the effectiveness of social implementation.

\section{KEY WORDS}

attitudes towards science; psychology of science; scientistic worldview; social image of science; beliefs about science

CORResponding AUthor - Łukasz Jach, Ph.D., Institute of Psychology, Department of Social Sciences,

University of Silesia, 53 Grażyńskiego Str., 40-126 Katowice, Poland, e-mail: lukasz.jach@us.edu.pl

authors' Contribution - A: Study design - B: Data collection - C: Statistical analysis - D: Data interpretation .

E: Manuscript preparation · F: Literature search · G: Funds collection

To Cite this ARTICLE - Jach, Ł. (2021). How to distinguish a "scientoskeptic" from a "scientoenthusiast"? Psychometric properties and criteria for qualitative interpretation of the scores of the Views of Science Questionnaire in a Polish quota sample. Current Issues in Personality Psychology, 9(1), 66-83.

RECEIVED 03.09.2020 • REVIEWED 29.09.2020 • ACCEPTED 02.11.2020 • PUBLISHED 25.03.2021 


\section{BACKGROUND}

Individual, social and cultural attitudes towards science are becoming more and more ambiguous. On the one hand, due to science development and scientific discoveries, the living conditions of most people on Earth have definitely improved over the last centuries (Pinker, 2018). On the other hand, scientists are accused of manipulating public opinion and acting in favor of political or economic interests (Goertzel, 2010; Harambam \& Aupers, 2015), as well as creating theories that threaten the current social order and traditional values (Edis, 2018). Sometimes, scientific statements are also considered as equal to other narratives about the world, without reasons to treat them in a privileged way (Kuntz, 2012). These phenomena have been clearly visible during the COVID-19 pandemic in 2020. Parallel to expectations placed on scientists, related to understanding the mechanisms of transmission of the virus and the development of treatments and vaccines, there have also been voices accusing scientists of creating the virus in the laboratory, and some scientific recommendations have been treated with skepticism or even resistance (Biddlestone et al., 2020; Imhoff \& Lamberty, 2020; Uscinski et al., 2020).

The attitude towards science, scientists and scientific discoveries is associated with numerous psychological variables and manifests itself in everyday behavior. As was demonstrated by Rutjens et al. (2018), faith in science shows negative associations with economic and social conservatism, belief in God, religious orthodoxy and identity, climate change skepticism, vaccine skepticism and moral values related to purity/degradation. The research of Shtulman and Valcarcel (2012) showed that the reception of scientific information can be more difficult when it collides with previous, intuitive beliefs. Research by Impey et al. (2012) indicates that beliefs not supported by science tend to coexist with scientific knowledge and may be not susceptible to changes even in the course of academic education. Research by Metz et al. (2018) shows that this phenomenon may be based on the use of a wide range of criteria for assessing information, including those based on religious, social, ethical or emotional aspects.

One of the psychological approaches related to people's attitudes towards science, scientists, and scientific discoveries is the construct of a scientistic worldview (Jach, 2015). According to this approach, a scientistic worldview is defined as a form of worldview characterized by the tendency to justify one's beliefs and behavior with scientific findings and to function on the basis of theorems formulated by scientists, which is connected with considering scientific language as the most perfect and the most valuable method of relating to the world and to the phenomena taking place in it (Jach, 2015, p. 154). A scientistic worldview does not need to be based on actual scientific knowledge but only convictions or opinions that appear to be embedded in a scientific context. To measure this worldview, a Views of Science Questionnaire (VoSQ) was designed (Jach, 2019).

The tool measures not only the general level of beliefs about the current meaning and functions of science but also four specific aspects of a scientistic worldview: trust in scientific method, perceiving scientists as the only experts, perceiving science as a source of hope, and perceiving science as a tool of practical influence. The Trust in Scientific Method scale measures the belief that science is based on undeniable foundations and that both the existence of the reality it describes and the methods used for this purpose are objectively certain. The Scientists as the Only Experts scale refers to the level of inclination to admire scientists and their role in the process of discovering the mysteries of the world, and to consider the competences of scientists as more important than the competences of other intellectuals (e.g. artists or philosophers). The Science as a Source of Hope scale measures the level of hope that any conflicts and anxieties accompanying humanity throughout its history are possible to eliminate thanks to scientific discoveries and recommendations. The Science as a Tool of Practical Influence scale measures the level of beliefs that science gives power over nature and provides tools to transform the environment in accordance with current preferences and needs.

The research conducted so far using the VoSQ has shown that an elevated level of scientistic worldview is associated with considering advertisements embedded in a scientific context as more credible (Jach \& Chmiel, 2018), a higher need for cognitive closure, higher admiration for the values related to power over people and resources, lower respect for values related to tradition, spirituality and community, a stronger tendency to make more pragmatic decisions, a more positive attitude towards vaccinations, higher aesthetic evaluation of graphics containing references to the scientific context and considering scientific reports as more credible (Jach, 2020).

The need to distinguish people skeptical about scientific findings from those who are science enthusiasts or show an average level of scientistic worldview seems to be particularly important in the context of social communication (Gauchat, 2011). Due to different attitudes towards the scientific system, some people may trust recommendations formulated directly by representatives of the field of science, while others rely on different authorities (Brewer \& Ley, 2013; Hendriks et al., 2016).

The article presents the results of research aimed at developing criteria for assessing the level of scientistic worldview, in the case of either individual people or groups. To achieve this, a survey was conducted using the Views of Science Questionnaire (Jach, 2019) on a Polish quota sample. Additionally, analyses of the psychometric properties of the tool regarding its reliability and factor structure were carried out. 


\section{PARTICIPANTS AND PROCEDURE}

\section{PARTICIPANTS}

1,119 people (560 female and 559 male) participated in the study. The age of the participants was between 18 and $87(M=48.90, S D=16.07)$. Among the surveyed participants, $121(10.81 \%)$ had primary or vocational education, 465 (41.56\%) had secondary education, and 533 (47.63\%) had higher education. More detailed information on gender, age and level of education of the participants is presented in Table 1.

\section{PROCEDURE}

The use of Views of Science Questionnaire in scientific research received a positive opinion from the Ethics Committee of the university employing the author. The study was conducted on a Polish quota sample, selected according to criteria of gender and age. Data were collected using the Polish online survey platform "Ariadna". Participation in the study was anonymous and voluntary. The participants were informed of the nature of the study. For participation in the study they received points that could be exchanged for gifts offered by the survey platform. During the survey procedure, the participants also completed two other questionnaires unrelated to the presented study.

The participants filled in the Views of Science Questionnaire (Jach, 2019). The tool consists of 16 statements, each with five possible answers (1 - definitely disagree, 2 - rather disagree, 3 - difficult to say, 4 - rather agree, 5 - definitely agree). The sum of the points obtained in all items is a score referring to the overall level of a scientistic worldview. In addition, the scores are calculated for the following subscales: Trust in Scientific Method, Scientists as the Only Experts, Science as a Source of Hope and Science as a Tool of Practical Influence (for the content of the items see the Appendix). The tool is characterized by a satisfactory level of reliability in relation to its overall score (Cronbach's $\alpha=.85$ ) and its subscales (Cronbach's alphas between .65 and .78). Previous studies have also shown a satisfactory level of stability of VoSQ results - the correlation coefficients of the measurements performed with the test-retest method within two weeks were .78 for the general score and from .58 to .75 for the subscale results (Jach, 2019).

\section{RESULTS}

\section{DESCRIPTIVE STATISTICS}

Table 2 presents descriptive statistics relating to each item of the VoSQ questionnaire and the results obtained for its general scale and subscales. The response frequency distributions for all items were different from the normal distribution. The negative skewness of the answers for each of the items indicates the prevalence of affirmative responses over negatives.

\section{RELIABILITY OF THE VIEWS OF SCIENCE QUESTIONNAIRE IN CURRENT RESEARCH}

When starting the psychometric analyses of VoSQ properties, it was decided to analyze the reliability of the tool. Related data are presented in Table 3.

The obtained values of Cronbach's $\alpha$ coefficients and the item-scale and item-item correlation coefficients indicated a satisfactory level of reliability of the general scale of the VoSQ as well as of its subscales. The highest level of reliability was found for

\section{Table 1}

Gender and education level of participants in particular age groups

\begin{tabular}{lcccc}
\hline & \multicolumn{4}{c}{ Age group } \\
\cline { 2 - 5 } & $\begin{array}{c}\text { Early adulthood } \\
\text { (age 18-34) }\end{array}$ & $\begin{array}{c}\text { Middle adulthood - } \\
\text { younger (age 35-49) }\end{array}$ & $\begin{array}{c}\text { Middle adulthood - } \\
\text { older (age 50-64) }\end{array}$ & $\begin{array}{c}\text { Late adulthood } \\
\text { (age 65+) }\end{array}$ \\
\hline Total & 279 & 279 & 281 & 280 \\
Female & $140(50.18 \%)$ & $140(50.18 \%)$ & $141(50.18 \%)$ & $139(49.64 \%)$ \\
Male & $139(19.81 \%)$ & $139(19.81 \%)$ & $140(49.82 \%)$ & $141(50.36 \%)$ \\
Education & $16(5.74 \%)$ & $37(13.26 \%)$ & $46(16.37 \%)$ & $22(7.86 \%)$ \\
$\quad$ Primary or vocational \\
$\quad$ Secondary \\
Higher
\end{tabular}


Table 2

Views of Science Questionnaire - descriptive statistics

\begin{tabular}{|c|c|c|c|c|c|}
\hline Item number & $M$ & $S D$ & Skewness & Kurtosis & Shapiro-Wilk \\
\hline 1 & 3.66 & 0.95 & -.53 & .22 & $.88^{* * *}$ \\
\hline 2 & 3.47 & 1.04 & -.40 & -.31 & $.90^{* * *}$ \\
\hline 3 & 3.48 & 0.96 & -.47 & .01 & $.89^{* * *}$ \\
\hline 4 & 3.74 & 0.96 & -.49 & -.10 & $.88^{* * *}$ \\
\hline 5 & 3.42 & 1.06 & -.44 & -.45 & $.90^{* * *}$ \\
\hline 6 & 3.50 & 1.01 & -.41 & -.16 & $.90^{* * *}$ \\
\hline 7 & 3.30 & 1.00 & -.28 & -.36 & $.90^{* * *}$ \\
\hline 8 & 3.16 & 1.08 & -.23 & -.58 & $.91^{* * *}$ \\
\hline 9 & 3.52 & 1.11 & -.40 & -.47 & $.90^{* * *}$ \\
\hline 10 & 3.15 & 1.06 & -.19 & -.54 & $.91^{* * *}$ \\
\hline 11 & 3.29 & 1.05 & -.21 & -.45 & $.91^{* * *}$ \\
\hline 12 & 3.21 & 1.02 & -.25 & -.29 & $.91^{* * *}$ \\
\hline 13 & 3.46 & 1.06 & -.35 & -.32 & $.90^{* * *}$ \\
\hline 14 & 3.10 & 1.01 & -.17 & -.30 & $.91^{* * *}$ \\
\hline 15 & 3.34 & 0.96 & -.38 & -.08 & $.89^{* * *}$ \\
\hline 16 & 3.14 & 1.08 & -.27 & -.53 & $.91^{* * *}$ \\
\hline TiSM & 14.02 & 3.05 & -.30 & .43 & $.97^{* * *}$ \\
\hline $\mathrm{SaOE}$ & 13.95 & 3.56 & -.39 & .06 & $.97^{* * *}$ \\
\hline SaSoH & 13.03 & 3.21 & -.27 & .30 & $.98^{* * *}$ \\
\hline SaToPI & 12.93 & 3.36 & -.28 & .05 & $.98^{* * *}$ \\
\hline SV-GS & 53.92 & 11.65 & -.30 & .52 & $.99^{* * *}$ \\
\hline
\end{tabular}

Note. ${ }^{* * *} p<.001 ; \mathrm{TiSM}$ - trust in scientific method; SaOE - scientists as the only experts; SaSoH - science as a source of hope; SaToPI - science as a tool of practical influence; SV-GS - general scientistic worldview.

the subscale Scientists as the Only Experts and the relatively lowest level of reliability was related to the Trust in the Scientific Method scale.

\section{FACTOR STRUCTURE OF THE VIEWS OF SCIENCE QUESTIONNAIRE}

Subsequently, it was decided to check whether the VoSQ factor structure in the current, Polish quota sample was identical to that identified at the stage of creating the tool (see Jach, 2019). For this purpose, a confirmatory factor analysis was performed using the diagonally weighted least squares (DWLS) estimator. This relatively universal estimator worked well when the collected data have non-normal distribution (Rhemtulla et al., 2012), as was the case in the current study.

It was decided to conduct a confirmatory analysis for three different models in parallel. The first was a model with a single general factor (scientistic worldview as the only variable). The second was a model with four independent but correlated factors (four aspects of scientistic worldview as independent but correlated variables). The last one was a model with one higher-order factor and four sub-factors (scientistic worldview and its four sub-aspects). Information on the level of fitness of mentioned models is presented in Table 4.

All tested models had a satisfactory level of the fit indices, but the model with a single general factor had relatively the worst fit. The other two models had similar levels of fit, while the one with four independent but correlated factors fitted slightly better. At the stage of creating the VoSQ (Jach, 2019), due to its greater interpretative potential, it was decided to use a model with one higher-order factor and four sub-factors in further analyses. The standardized values of the regression coefficients $(\beta)$ in the mentioned model are presented in Table 5. 


\section{GENDER, AGE AND EDUCATIONAL COMPARISONS OF THE LEVEL OF SCIENTISTIC WORLDVIEW}

One of the aims of the conducted analyses was to develop criteria for the qualitative interpretation of the VoSQ results. Therefore, it was decided to check whether it was sufficient to develop only general criteria, or whether it was necessary to develop such

Table 3

Internal consistency of Views of Science Questionnaire scales

\begin{tabular}{lccc}
\hline $\begin{array}{l}\text { VoSQ } \\
\text { Scale }\end{array}$ & $\begin{array}{c}\text { Cronbach's } \\
\alpha\end{array}$ & $\begin{array}{c}\text { Mean } \\
\text { item-scale } \\
\text { correlation }\end{array}$ & $\begin{array}{c}\text { Mean } \\
\text { item-item } \\
\text { correlation }\end{array}$ \\
\hline TiSM & .78 & .59 & .48 \\
SaOE & .87 & .72 & .62 \\
SaSoH & .81 & .62 & .51 \\
SaToPI & .81 & .62 & .51 \\
SV-GS & .93 & .66 & .47 \\
\hline
\end{tabular}

Note. TiSM - trust in scientific method; $\mathrm{SaOE}$ - scientists as the only experts; $\mathrm{SaSoH}$ - science as a source of hope; $\mathrm{SaToPI}$ - science as a tool of practical influence; SV-GS - general scientistic worldview. criteria for groups differentiated in demographic terms. For this purpose, the scores of the VoSQ scales were compared in groups of different gender, age and level of education. Due to the non-normality of the distributions of the studied variables (see Table 2), it was decided to use non-parametric methods of statistical analyses.

The Mann-Whitney $U$ test (see Table 6) showed that the male participants had a higher level of scientistic worldview than the female participants. With regard to particular aspects of this worldview, the male participants had a stronger tendency to consider scientists as the only experts, consider science as a source of hope, and consider science as a tool of practical influence. On the other hand, regardless of gender, the participants showed similar levels of trust in the scientific method.

As shown in Table 7, the age of the participants was positively correlated with the scores of all VoSQ scales. Although correlations between age and aspects of scientist worldview suggested that older participants had higher respect and trust for elements of the scientific system, the strength of the reported relationships was very low. Moreover, comparisons between particular age groups (see Table 8) showed that only the oldest respondents had a higher level of the scientistic worldview than members of other age groups and there were no significant differences between young adults and middle adults.

Table 4

Model fit coefficients in confirmatory factor analysis

\begin{tabular}{lccccccc}
\hline Model & $\chi^{2} / d f$ & GFI & PGFI & CFI & RMSEA $(90 \%$ CI) & SRMR \\
\hline One general factor & 2.85 & .991 & .988 & .991 & $.041(.035-.046)$ & .053 \\
Four independent but correlated factors & 1.80 & .994 & .992 & .996 & $.020(.021-.033)$ & .041 \\
Four sub-factors and one higher order factor & 2.12 & .993 & .991 & .995 & $.032(.026-.038)$ & .045 \\
\hline
\end{tabular}

Table 5

Standardized regression coefficients $(\beta)$ in the hierarchical model

\begin{tabular}{|c|c|c|c|c|c|c|c|c|c|c|c|c|c|c|c|c|}
\hline \multirow[t]{2}{*}{ Model } & \multicolumn{16}{|c|}{ Item number } \\
\hline & 1 & 4 & 11 & 15 & 2 & 6 & 9 & 13 & 3 & 7 & 10 & 14 & 5 & 8 & 12 & 16 \\
\hline TiSM & .57 & .68 & .71 & .78 & & & & & & & & & & & & \\
\hline $\mathrm{SaOE}$ & & & & & .75 & .85 & .73 & .81 & & & & & & & & \\
\hline SaSoH & & & & & & & & & .68 & .71 & .75 & .72 & & & & \\
\hline SaToPI & & & & & & & & & & & & & .64 & .70 & .72 & .79 \\
\hline SV-GS & \multicolumn{4}{|c|}{.98} & \multicolumn{4}{|c|}{.89} & \multicolumn{4}{|c|}{.92} & \multicolumn{4}{|c|}{.94} \\
\hline
\end{tabular}

Note. All $\beta$-values statistically significant $(p<.001)$; TiSM - trust in scientific method; SaOE - scientists as the only experts; $\mathrm{SaSoH}$ - science as a source of hope; SaToPI - science as a tool of practical influence; SV-GS - general scientistic worldview. 
The levels of scientistic worldview were also compared in groups that differed in terms of the level of education. The one-way ANOVA on ranks analyses did not reveal any differences between the groups of respondents with primary or vocational, secondary and higher education (see Table 9).

\section{CRITERIA FOR QUALITATIVE INTERPRETATION OF VIEWS OF SCIENCE QUESTIONNAIRE SCORES}

Based on the collected data and the results presented in the previous subsections, criteria for the qualitative interpretation of the VoSQ scores were developed, making it possible to define the score of a concrete person as "low", "average", "high," etc. Taking into account the gender and age differences in the scientistic worldview described above, not only general criteria, but also criteria for people with different gender aged 18 to 64, and aged 65+ were developed. Due to the higher interpretative potential and possible further transformations of the results, it was decided to base the qualitative interpretation of the VoSQ questionnaire scores on the percentage of respondents falling within specific ranges of the scores obtained. Information on the frequencies of scores on the general VoSQ scale as well as its sub- scales is presented in the Appendix (see Table A and Table B).

Taking into account the frequencies of scores, it was decided to assign particular results with percentile ranks and qualitative interpretation related to them. It made it possible to define the scores obtained as very low (percentiles $\leq 2$ ), low (percentiles 3-10), below average (percentiles 11-24), average (percentiles 25-75), above average (percentiles 76-89), high

\section{Table 6}

Gender comparisons of scientistic worldview aspects

\begin{tabular}{lccc}
\hline $\begin{array}{l}\text { VoSQ } \\
\text { Scale }\end{array}$ & $\begin{array}{c}\text { Female }- \\
\text { mean rank }\end{array}$ & $\begin{array}{c}\text { Male }- \\
\text { mean rank }\end{array}$ & Z corrected \\
\hline TiSM & 542.19 & 577.85 & -1.86 \\
SaOE & 516.85 & 603.23 & $-4.49^{* * *}$ \\
SaSoH & 527.32 & 592.74 & $-3.41^{* * *}$ \\
SaToPI & 536.23 & 583.81 & $-2.48^{*}$ \\
SV-GS & 526.31 & 593.75 & $-3.49^{* * *}$ \\
\hline
\end{tabular}

Note. ${ }^{*} p<.05,{ }^{* * *} p<.001 ;$ TiSM - trust in scientific method; $\mathrm{SaOE}$ - scientists as the only experts; $\mathrm{SaSoH}$ - science as a source of hope; SaToPI - science as a tool of practical influence; SV-GS - general scientistic worldview.

\section{Table 7}

Correlations between aspects of scientistic worldview and participants' age

\begin{tabular}{lccccc}
\hline VoSQ Scale & TiSM & SaOE & SaSoH & SaToPI & SV-GS \\
\hline Age & $.21^{* * *}$ & $.16^{* * *}$ & $.07^{*}$ & $.09^{* *}$ & $.15^{* * *}$ \\
\hline $\begin{array}{l}\text { Note. }{ }^{*} p<.05,{ }^{* *} p<.01,{ }^{* * *} p<.001 ; \text { TiSM }- \text { trust in scientific method; SaOE - scientists as the only experts; SaSoH - science as } \\
\text { a source of hope; SaToPI }- \text { science as a tool of practical influence; SV-GS - general scientistic worldview. }\end{array}$
\end{tabular}

\section{Table 8}

Comparisons of VoSQ scores in groups stratified by age - one-way ANOVA on ranks test

\begin{tabular}{|c|c|c|c|c|c|}
\hline \multirow{2}{*}{$\begin{array}{l}\text { VoSQ } \\
\text { Scale }\end{array}$} & \multirow{2}{*}{$\begin{array}{c}H \text { Kruskal- } \\
\text { Wallis } \\
(3, N=1119)\end{array}$} & \multicolumn{4}{|c|}{ Mean ranks } \\
\hline & & $\begin{array}{l}\text { Early adulthood } \\
\text { (age 18-34) }\end{array}$ & $\begin{array}{l}\text { Middle adulthood - } \\
\text { younger (age 35-49) }\end{array}$ & $\begin{array}{l}\text { Middle adulthood - } \\
\text { older (age 50-64) }\end{array}$ & $\begin{array}{l}\text { Late adulthood } \\
\qquad(65+)\end{array}$ \\
\hline TiSM & $61.74^{* * *}$ & 485.92(a) & $532.35(\mathrm{a})$ & $535.35(\mathrm{a})$ & $686.10(b)$ \\
\hline $\mathrm{SaOE}$ & $44.03^{* * *}$ & $515.36(a)$ & $534.67(a)$ & $520.15(a)$ & $669.71(b)$ \\
\hline SaSoH & $20.47^{* * *}$ & 550.12 & 550.34 & $510.03(\mathrm{a})$ & $629.63(b)$ \\
\hline SaToPI & $31.29^{* * *}$ & 546.70 & 550.12 & 497.58(a) & $645.74(b)$ \\
\hline SV-GS & $46.25^{* * *}$ & $517.06(\mathrm{a})$ & $541.37(\mathrm{a})$ & $509.72(\mathrm{a})$ & 671.82(b) \\
\hline
\end{tabular}

Note. Different letters in brackets means statistically significant statistical difference at the $p$ level $<.001 ;$ TiSM - trust in scientific method; SaOE - scientists as the only experts; SaSoH - science as a source of hope; SaToPI - science as a tool of practical influence; SV-GS - general scientistic worldview. 
Table 9

Comparisons of VoSQ scores in groups stratified by educational level - one-way ANOVA on ranks test

\begin{tabular}{lcc}
\hline VoSQ Scale & $\begin{array}{c}H \text { Kruskal-Wallis } \\
(2, N=1119)\end{array}$ & $p$ \\
\hline TiSM & 3.16 & .207 \\
SaOE & 3.70 & .157 \\
SaSoH & 3.33 & .189 \\
SaToPI & 0.72 & .698 \\
SV-GS & 1.87 & .392 \\
\hline
\end{tabular}

Note. TiSM - trust in scientific method; SaOE - scientists as the only experts; $\mathrm{SaSoH}$ - science as a source of hope; SaToPI - science as a tool of practical influence; SV-GS - general scientistic worldview. (percentiles 90-97) and very high (percentiles $\geq 98$ ). Qualitative interpretations referring to particular ranges of general VoSQ scores are presented in Table 10 (for qualitative interpretation of ranges of VoSQ subscale scores see Table C in the Appendix).

The data presented in Table 10 (and also Table C in the Appendix) made it possible to determine the level of one's scientistic worldview, compared to the participants of the Polish quota sample characterized by gender and age. In research on the psychological aspects of the scientistic worldview, it may also be useful to determine whether the studied groups have a generally high, low or average level of scientistic worldview compared to the mentioned reference group. To make it possible, the descriptive statistics of Views of Science Questionnaire results were also counted in particular subgroups of participants. The related data were included in Table 11.

\section{Table 10}

Qualitative interpretation of Views of Science Questionnaire general scores

\begin{tabular}{lcccccccc}
\hline Percentiles & Interpretation & All & $\begin{array}{c}18-64 \\
\text { All }\end{array}$ & $\begin{array}{c}18-64 \\
\text { Female }\end{array}$ & $\begin{array}{c}18-64 \\
\text { Male }\end{array}$ & $\begin{array}{r}65+ \\
\text { All }\end{array}$ & $\begin{array}{c}65+ \\
\text { Female }\end{array}$ & $\begin{array}{c}65+ \\
\text { Male }\end{array}$ \\
\hline$\leq 99$ & Very high & $78-80$ & $77-80$ & $76-80$ & $78-80$ & $78-80$ & $77-80$ & 80 \\
$90-98$ & High & $68-77$ & $66-76$ & $64-75$ & $67-77$ & $74-77$ & $72-76$ & $75-79$ \\
$76-89$ & Above average & $62-67$ & $60-65$ & $59-63$ & $62-66$ & $65-73$ & $64-71$ & $67-74$ \\
$25-75$ & Average & $48-61$ & $47-59$ & $46-58$ & $48-61$ & $50-64$ & $48-63$ & $52-66$ \\
$11-24$ & Below average & $40-47$ & $39-46$ & $39-45$ & $41-47$ & $43-49$ & $41-47$ & $48-51$ \\
$3-10$ & Low & $26-39$ & $24-38$ & $24-38$ & $24-40$ & $31-42$ & $31-40$ & $29-47$ \\
$\leq 2$ & Very low & $16-25$ & $16-23$ & $16-23$ & $16-23$ & $16-30$ & $16-30$ & $16-28$ \\
\hline
\end{tabular}

\section{Table 11}

Descriptive statistics of Views of Science Questionnaire in subgroups

\begin{tabular}{|c|c|c|c|c|}
\hline Scale & Group & $M$ & $S D$ & Median \\
\hline \multirow{9}{*}{$\begin{array}{l}\text { Views of Science Questionnaire - } \\
\text { general }\end{array}$} & All $(N=1119)$ & 53.92 & 11.65 & 54 \\
\hline & Female $(n=560)$ & 52.75 & 11.35 & 52 \\
\hline & Male $(n=559)$ & 55.11 & 11.83 & 55 \\
\hline & $18-64$ All $(N=839)$ & 52.58 & 11.42 & 52 \\
\hline & 18-64 Female $(n=421)$ & 51.57 & 11.16 & 51 \\
\hline & 18-64 Male $(n=418)$ & 53.56 & 11.61 & 53 \\
\hline & $65+\operatorname{All}(N=280)$ & 57.95 & 11.40 & 59 \\
\hline & $65+$ Female $(n=139)$ & 56.30 & 11.22 & 57 \\
\hline & $65+$ Male $(n=141)$ & 59.58 & 11.37 & 60 \\
\hline
\end{tabular}


Table 11

Table 11 continued

\begin{tabular}{|c|c|c|c|c|}
\hline Scale & Group & $M$ & $S D$ & Median \\
\hline \multirow[t]{9}{*}{ Trust in Scientific Method } & All $(N=1119)$ & 14.02 & 3.05 & 14 \\
\hline & Female $(n=560)$ & 13.87 & 2.91 & 14 \\
\hline & Male $(n=559)$ & 14.17 & 3.19 & 14 \\
\hline & $18-64$ All $(N=839)$ & 13.61 & 3.02 & 14 \\
\hline & $18-64$ Female $(n=421)$ & 13.46 & 2.85 & 13 \\
\hline & 18-64 Male $(n=418)$ & 13.77 & 3.18 & 14 \\
\hline & $65+\operatorname{All}(N=280)$ & 15.23 & 2.83 & 15 \\
\hline & $65+$ Female $(n=139)$ & 15.11 & 2.73 & 15 \\
\hline & $65+$ Male $(n=141)$ & 15.35 & 2.92 & 16 \\
\hline \multirow[t]{9}{*}{ Scientists as the Only Experts } & All $(N=1119)$ & 13.95 & 3.56 & 14 \\
\hline & Female $(n=560)$ & 13.49 & 3.50 & 13 \\
\hline & Male $(n=559)$ & 14.40 & 3.56 & 15 \\
\hline & $18-64$ All $(N=839)$ & 13.55 & 3.51 & 13 \\
\hline & $18-64$ Female $(n=421)$ & 13.14 & 3.45 & 13 \\
\hline & 18-64 Male $(n=418)$ & 13.97 & 3.52 & 14 \\
\hline & $65+\operatorname{All}(N=280)$ & 15.12 & 3.45 & 15 \\
\hline & $65+$ Female $(n=139)$ & 14.55 & 3.43 & 15 \\
\hline & $65+$ Male $(n=141)$ & 15.69 & 3.39 & 16 \\
\hline \multirow[t]{9}{*}{ Science as a Source of Hope } & All $(N=1119)$ & 13.03 & 3.21 & 13 \\
\hline & Female $(n=560)$ & 12.70 & 3.13 & 13 \\
\hline & Male $(n=559)$ & 13.36 & 3.26 & 13 \\
\hline & $18-64$ All $(N=839)$ & 12.79 & 3.18 & 13 \\
\hline & $18-64$ Female $(n=421)$ & 12.54 & 3.08 & 12 \\
\hline & 18-64 Male $(n=418)$ & 12.79 & 3.18 & 13 \\
\hline & $65+\operatorname{All}(N=280)$ & 13.76 & 3.20 & 14 \\
\hline & $65+$ Female $(n=139)$ & 13.20 & 3.23 & 13 \\
\hline & $65+$ Male $(n=141)$ & 14.31 & 3.10 & 14 \\
\hline \multirow{9}{*}{$\begin{array}{l}\text { Science as a Tool of Practical } \\
\text { Influence }\end{array}$} & All $(N=1119)$ & 12.93 & 3.36 & 13 \\
\hline & Female $(n=560)$ & 12.69 & 3.32 & 13 \\
\hline & Male $(n=559)$ & 13.17 & 3.38 & 13 \\
\hline & $18-64$ All $(N=839)$ & 12.63 & 3.29 & 13 \\
\hline & 18-64 Female $(n=421)$ & 12.44 & 3.28 & 12 \\
\hline & 18-64 Male $(n=418)$ & 12.81 & 3.30 & 13 \\
\hline & $65+\operatorname{AII}(N=280)$ & 13.84 & 3.39 & 14 \\
\hline & $65+$ Female $(n=139)$ & 13.44 & 3.35 & 14 \\
\hline & $65+$ Male $(n=141)$ & 14.24 & 3.40 & 14 \\
\hline
\end{tabular}




\section{DISCUSSION}

\section{PSYCHOMETRIC PROPERTIES OF THE VIEWS OF SCIENCE QUESTIONNAIRE}

One of the aims of the research was to verify the psychometric properties of the VoSQ on a Polish quota sample. Cronbach's $\alpha$ coefficients as well as the itemscale and item-item correlation coefficients indicated a satisfactory level of reliability. In the study, the obtained reliability coefficients achieved even higher values than those reported at the stage of constructing and validating the tool (Jach, 2019). This leads to considering the VoSQ as a tool enabling accurate measurements of the studied constructs related to the attitude to science, scientists and scientific discoveries.

In the confirmatory factor analysis, models with (a) a single general factor, (b) four independent but correlated factors and (c) four factors related to one higher-order factor were compared. Although for each of the mentioned solutions satisfactory fit indices were obtained, the lowest level of fit characterized the one-dimensional solution. The higher level of fit of the multidimensional solutions provides motivation to include the results of the VoSQ subscales in the analyses of the collected data.

Although the highest level of fit was obtained for the solution with four equal factors, due to the greater interpretative potential, it seems reasonable to use a solution that also takes into account a higher-order factor, which may be interpreted as an indicator of the general level of one's scientistic worldview. Slight differences between the model with four parallel factors and the model with a higher-order factor were also noted in four studies conducted during the construction of the tool (Jach, 2019), and also in that case there were no psychometric reasons for rejecting any of them. Therefore, a decision was made to choose the " $4+1$ " solution due to its higher interpretative potential.

\section{QUALITATIVE INTERPRETATION OF THE VIEWS OF SCIENCE QUESTIONNAIRE SCORES}

At the very start of developing the criteria for interpreting VoSQ scores, the necessity to create different criteria for groups stratified by gender, age and level of education was checked. At the design stage of the tool, no gender differences in the level of aspects of the scientistic worldview were noted (Jach, 2019). However, they appeared in the current study for most VoSQ subscales as well as its general scale. The surveyed male participants were characterized by a higher level of considering scientists as the only experts, considering science as a source of hope and a tool of practical influence as well as their higher general level of scientistic worldview. The current study, however, was conducted on a much larger and more balanced sample in terms of the gender aspects compared to the previous studies. Therefore, it seems justified to assume that the male participants may be characterized by a higher level of scientistic worldview than the female ones, which implies different criteria for the qualitative interpretation of the VoSQ results for the two genders.

In the current research, weak positive correlations were observed between aspects of scientistic worldview and the age of the respondents. The comparisons of the results obtained in the VoSQ scales in particular age groups showed, however, that only the oldest participants $(65+)$ were characterized by a higher level of the measured variables than the members of the other age groups. Therefore, it was decided to develop specific criteria for the qualitative interpretation of the VoSQ results for this age group.

The higher level of scientistic worldview among people aged $65+$ can be interpreted in two ways. On the one hand, it may be associated with a higher level of respect and recognition for institutions and authorities, characteristic of older people in Poland (GUS, 2015). On the other hand, the causes for the observed results may lie in the methodology of the study. Because the study was conducted via the Internet, the older participants may have been characterized by a higher level of interest in technology and in the modern world (see McDonough, 2016) than the global population of older people in Poland. The affirmative attitude of the oldest participants towards the statements of the VoSQ tool could therefore be partially motivated by their desire to maintain their own image of people who are still well up on the contemporary world, in which the scientific context plays a very important role (see e.g. the effects of third age learning programs on the life satisfaction, self-esteem, and depression level of older people in: Escolar-Chua \& de Guzman, 2014).

The research did not reveal any differences in scientistic worldview between participants with different levels of education. Very similar results were obtained at the stage of constructing the questionnaire (Jach, 2019), where slight differences related to education were noted only in some samples, and only in the case of some of the VoSQ scales. The reported results indicate that there is no need to develop different criteria for the qualitative interpretation of the VoSQ scores for people with different levels of education. From a different perspective, these results clearly strengthen one of the fundamental theoretical assumptions of the theory of scientistic worldview, which states that this kind of worldview is not so much related to actual knowledge, but rather based on convictions or opinions that only appear to be embedded in a scientific context (Jach, 2015, 2020). 
It should be mentioned that among the surveyed people there were $10.8 \%$ respondents with education below secondary, $41.6 \%$ with secondary education and $47.6 \%$ with higher education. These data can be compared with the results of the 2019 Eurostat survey on the education of Poles aged 18-69 (percentages of levels of education respectively: $10.4 \%$, $61.6 \%$ and $28.0 \%$ ). In this context one may say that the studied sample included an appropriate percentage of people with lower than secondary education, but people with higher education were noticeably over-represented in relation to people with secondary education.

The criteria for the qualitative interpretation of individual results were based on percentile ranks, making it possible to label the concrete scores as very low, low, below average, average, above average, high, and very high. The scope of these categories is wide, but sometimes it may not meet the specific needs of a particular study. However, based on the data in Tables A and B (see Appendix), it is possible to assign the scores achieved to other categories, such as "below / above median" or " $33^{\text {rd }}$ percentile and below / between the $33^{\text {rd }}$ and $66^{\text {th }}$ percentile / $67^{\text {th }}$ percentile and above". Therefore, although it was proposed to interpret the scores on the basis of the data from Table 10, thanks to the information contained in Tables A and B, the users of the tool still have a lot of freedom in their own interpretation of the scores.

In order to enable a qualitative interpretation of the scores obtained in the entire surveyed samples to be given, Table 11 contains information making it possible to treat the surveyed Polish quota sample as a reference group. Using it makes it possible to check whether the samples in other studies (covering e.g. representatives of specific professional groups, supporters of certain political doctrines or people with specific social and moral attitudes) are characterized by a higher, lower or similar level of scientistic worldview compared to the Polish quota sample. These data may complement the range of results obtained in such studies with information on whether the current group consists of people more skeptical than, more enthusiastic than, or quite similar to the relatively big sample mentioned above.

The research conducted on a Polish quota sample confirmed the structure and satisfactory psychometric properties of the VoSQ and made it possible to establish criteria for the qualitative interpretation of the scores achieved. However, using samples recruited via the Internet in scientific research entails certain limitations that should be taken into account during the interpretation of the results obtained or when introducing actions based on them. First, the sampling criteria took into account only the gender and age of the respondents, disregarding other demographic variables. Secondly, the studied sample was composed of people recruited via the Internet who may not accurately reflect the characteristics of the general population of Poles. This aspect has been mentioned earlier, indicating the increased percentage of people with higher education and the possible differences between Internet users aged 65+ and other people of this age.

The first of the above-mentioned limitations could be overcome by adding extra selection criteria for the sample (e.g. education or place of residence) in subsequent, wider studies. The second one may be overcome by conducting a paper-and-pencil study in a group of people aged $65+$ and comparing the obtained results with the same results from the Internet sample to see if there are any differences. There is, however, a third limitation related to using results collected via an online survey platform in scientific research. Although it is increasingly common (Buhrmester et al., 2018), the question arises whether the participants of such studies do not differ significantly from the general population, e.g. in their motivations or tendencies to provide a specific type of answer (Hauser et al., 2019; Wessling et al., 2017). Considering that, on the one hand, it seems justified to treat the currently developed criteria for the qualitative interpretation of VoSQ scores as a significant extension of the research potential offered by this tool. On the other hand, it is worth considering conducting a similar study on a sample collected using the "paper-and-pencil" method. From a different perspective, there is no method of collecting survey data free from the risk of any distortion of the results. Moreover, as a result of the current information technology development and the increased epidemiological risks, research conducted via the Internet should be expected to become more and more common.

\section{CONCLUSIONS}

Nowadays, the relationship between science and its social reception is becoming an increasingly important issue. It is important not only from the point of view of implementing scientific recommendations in everyday life, but also in terms of the general perception of the world (e.g. Rull, 2014), the range of socially accepted directions of scientific research (Gupta et al., 2012; Seoyong \& Sunhee, 2015) and the amount of money spent on research (Motta, 2019). For this reason, the search for psychological methods of measurement and diagnosis of both individual and group beliefs about the role of science in the contemporary world is becoming an increasingly important task.

The Views of Science Questionnaire is a tool that explores many dimensions of attitudes towards science, scientists and elements of the scientific system. The presented research conducted on a quota sample 
of Polish Internet users confirmed the satisfactory reliability level of this tool and its factor structure consisting of one higher-order factor and four specific sub-factors: trust in scientific method, scientists as the only experts, science as a source of hope, and science as a tool of practical influence. The developed criteria of qualitative interpretation of both individual and group scores significantly expanded the scope of possible interpretations of data collected using the questionnaire. This knowledge may be useful in social implementation of scientific solutions, aimed at e.g. health prevention or improving the quality of life. One possible way to use information on the level of scientistic worldview may involve identifying individuals or groups with a low level of trust in science and scientists, and checking which other authorities have particular trust among them. This knowledge could be used to design messages consistent with scientific knowledge, but communicated to these people precisely through the mentioned authorities not associated directly with the scientific system. The very topical line of research using the VoSQ could also include exploring the relationship between the scientistic worldview and adherence to recommendations for preventing the spread of the SARS-CoV-2 virus.

\section{REFERENCES}

Biddlestone, M., Green, R., \& Douglas, K. M. (2020). Cultural orientation, power, belief in conspiracy theories, and intentions to reduce the spread of COVID-19. British Journal of Social Psychology, 59, 663-673. https://doi.org/10.1111/bjso.12397

Brewer, P. R., \& Ley, B. L. (2013). Whose science do you believe? Explaining trust in sources of scientific information about the environment. Science Communication, 35, 115-137. https://doi.org/ 10.1177/1075547012441691

Buhrmester, M. D., Talaifar, S., \& Gosling, S. D. (2018). An evaluation of Amazon's Mechanical Turk, its rapid rise, and its effective use. Perspectives on Psychological Science, 13, 149-154. https:// doi.org/10.1177/1745691617706516

Edis, T. (2018). Cosmic conspiracy theories: How theologies evade science: From genesis to astrobiology. In J. Seckbach \& R. Gordon (Eds.), Theology and science (pp. 143-165). World Scientific Publishing.

Escolar-Chua, R. L., \& de Guzman, A. B. (2014) Effects of third age learning programs on the life satisfaction, self-esteem, and depression level among a select group of community dwelling Filipino elderly. Educational Gerontology, 40, 77-90, https://doi.org/ 10.1080/03601277.2012.701157

Gauchat, G. (2011). The cultural authority of science: Public trust and acceptance of organized science. Public Understanding of Science, 20, 751-770. https://doi.org/10.1177/0963662510365246
Goertzel, T. (2010). Conspiracy theories in science. EMBO Reports, 11, 493-499. https://doi.org/10.1038/ embor.2010.84

Gupta, N., Fischer, A. R., \& Frewer, L. J. (2012). Socio-psychological determinants of public acceptance of technologies: a review. Public Understanding of Science, 21, 782-795. https://doi.org/ $10.1177 / 0963662510392485$

GUS (2015). Wartości i zaufanie spoteczne w Polsce w 2015 r. [Values and social trust in Poland in 2015]. Główny Urząd Statystyczny.

Harambam, J., \& Aupers, S. (2015). Contesting epistemic authority: Conspiracy theories on the boundaries of science. Public Understanding of Science, 24, 466-480. https://doi.org/10.1177/0963662514559891

Hendriks, F., Kienhues, D., \& Bromme, R. (2016). Trust in science and the science of trust. In B. Blöbaum (Ed.), Progress in IS. Trust and communication in a digitized world: Models and concepts of trust research (pp. 143-159). Springer International Publishing.

Hauser, D., Paolacci, G., \& Chandler, J. (2019). Common concerns with MTurk as a participant pool. In F. R. Kardes, P. M. Herr, \& N. Schwarz (Eds.), Handbook of research methods in consumer psychology (pp. 319-337). Routledge.

Imhoff, R., \& Lamberty, P. (2020). A bioweapon or a hoax? The link between distinct conspiracy beliefs about the coronavirus disease (COVID-19) outbreak and pandemic behavior. Social Psychological and Personality Science, 11, 1110-1118. https://doi.org/10.1177/1948550620934692

Impey, C., Buxner, S., \& Antonellis, J. (2012). Nonscientific beliefs among undergraduate students. Astronomy Education Review, 11. https://doi.org/ 10.3847/AER2012016

Jach, Ł. (2015). Nauka jako obiekt kultu. Wprowadzenie do koncepcji scjentoteizmu [Science as an object of worship. Introduction to the theory of scientotheism]. Wydawnictwo Uniwersytetu Śląskiego.

Jach, Ł. (2019). Spotlight on scientotheism. Structure and psychometic properties of the questionnaire for the study of scientistic worldview aspects. The Review of Psychology, 62, 141-165.

Jach, Ł. (2020). Światopoglad scjentystyczny - korelaty $i$ uwarunkowania [Scientistic worldview - correlates and conditions]. Wydawnictwo Uniwersytetu Śląskiego.

Jach, Ł., \& Chmiel, S. (2018). The reliability of advertising, the rule of social proof and the rule of scientific authority. Polish Journal of Economic Psychology, 13, 19-34. https://doi.org/10.15678/PJOEP.2018.13.02

Kuntz, M. (2012). The postmodern assault on science. If all truths are equal, who cares what science has to say? EMBO Reports, 13, 885-889. https://doi. org/10.1038/embor.2012.130

McDonough, C. C. (2016). The effect of ageism on the digital divide among older adults. Journal of Ger- 
ontology and Geriatric Medicine, 2, 008. https://doi. org/10.24966/GGM-8662/100008

Metz, S. E., Weisberg, D. S., \& Weisberg, M. (2018), Non-scientific criteria for belief sustain counterscientific beliefs. Cognitive Science, 42, 1477-1503. https://doi.org/10.1111/cogs. 12584

Motta, M. (2019). Explaining science funding attitudes in the United States: The case for science interest. Public Understanding of Science, 28, 161176. https://doi.org/10.1177/0963662518795397

Pinker, S. (2018). Enlightenment now: The case for reason, science, humanism, and progress. Penguin Books.

Rhemtulla, M., Brosseau-Liard, P., \& Savalei, V. (2012). When can categorical variables be treated as continuous? A comparison of robust continuous and categorical SEM estimation methods under suboptimal conditions. Psychological Methods, 17, 354-373. https://doi.org/10.1037/a0029315

Rull, V. (2014). The most important application of science: As scientists have to justify research funding with potential social benefits, they may well add education to the list. EMBO Reports, 15, 919922. https://doi.org/10.15252/embr.201438848

Rutjens, B. T., Sutton, R. M., \& van der Lee, R. (2018). Not all skepticism is equal: Exploring the ideological antecedents of science acceptance and rejection. Personality and Social Psychology Bulletin, 44, 384-405. https://doi.org/10.1177/0146167217741314

Seoyong, K., \& Sunhee, K. (2015) The role of value in the social acceptance of science-technology. International Review of Public Administration, 20, 305322. https://doi.org/10.1080/12294659.2015.1078081

Shtulman, A., \& Valcarcel, J. (2012). Scientific knowledge suppresses but does not supplant earlier intuitions. Cognition, 124, 209-215. https://doi.org/ 10.1016/j.cognition.2012.04.005

Uscinski, J. E., Enders, A. M., Klofstad, C. A., Seelig, M. I., Funchion, J. R., Everett, C., Wuchty, S., Premaratne, K., \& Murthi, M. N. (2020). Why do people believe COVID-19 conspiracy theories? The Harvard Kennedy School (HKS) Misinformation Review, 1. https://doi.org/10.37016/mr-2020-015

Wessling, K. S., Huber, J., \& Netzer, O. (2017). MTurk character misrepresentation: Assessment and solutions. Journal of Consumer Research, 44, 211-230. https://doi.org/10.1093/jcr/ucx053 


\section{VIEWS OF SCIENCE QUESTIONNAIRE}

Below you can find a list of statements related to the domain of science, scientists and scientific discoveries. Please indicate your level of acceptance for each of these statements.

1 - definitely disagree

2 - rather disagree

3 - difficult to say

4 - rather agree

5 - definitely agree

1. Doubting in the objectivity of science is like doubting the world's existence.

$\begin{array}{lllll}1 & 2 & 3 & 4 & 5\end{array}$

2. Scientists may replace philosophers and priests in their attempts to answer questions that have been puzzling mankind for thousands of years.

3. Scientific discoveries make the old-time divisions between humans less important.

$\begin{array}{lllll}1 & 2 & 3 & 4 & 5\end{array}$

4. People who doubt in the fundamentals of science are in fact unable to grasp them.

$\begin{array}{lllll}1 & 2 & 3 & 4 & 5\end{array}$

5. Science is the reason why humans could take control over nature.

$\begin{array}{lllll}1 & 2 & 3 & 4 & 5\end{array}$

6. If truth exists, the only way to reach it is through scientific cognition.

$\begin{array}{lllll}1 & 2 & 3 & 4 & 5\end{array}$

7. Discoveries and scientific knowledge help to reduce conflicts between people.

$\begin{array}{lllll}1 & 2 & 3 & 4 & 5\end{array}$

8. Even such phenomena as love, art, friendship and faith can be described and explained thanks to science.

9. Scientists' work is more useful than the work of priests, philosophers or artists.

$\begin{array}{lllll}1 & 2 & 3 & 4 & 5\end{array}$

10. The discoveries of scientists make us feel less and less anxious about our future.

11. What cannot be discovered by science is something mankind cannot know.

$\begin{array}{lllll}1 & 2 & 3 & 4 & 5\end{array}$

12. Due to the progress of science, we will soon be able to modify the real world according to our needs.

13. Even the boldest scientific conceptions are more rational than philosophical or religious ideas.

14. Due to the progress of science, different worldviews will become a more seldom reason for conflicts between people.

15. Scientific theories are based on fundamentals that cannot be disputed.

Key:

Trust in scientific method: $1+4+11+15$

Scientists as the only experts: $2+6+9+13$

Science as a source of hope: $3+7+10+14$

Science as a tool of practical influence: $5+8+12+16$

General score: the sum of points obtained for all items 
Table A

Cumulative frequencies of general scores of Views of Science Questionnaire

\begin{tabular}{|c|c|c|c|c|c|c|c|}
\hline \multirow{2}{*}{$\begin{array}{l}\text { VoSQ } \\
\text { general } \\
\text { scores }\end{array}$} & \multicolumn{7}{|c|}{ Cumulated frequencies of scores } \\
\hline & All & $\begin{array}{c}18-64 \\
\text { All }\end{array}$ & $\begin{array}{c}18-64 \\
\text { Female }\end{array}$ & $\begin{array}{l}18-64 \\
\text { Male }\end{array}$ & $\begin{array}{r}65+ \\
\text { All }\end{array}$ & $\begin{array}{c}65+ \\
\text { Female }\end{array}$ & $\begin{array}{c}65+ \\
\text { Male }\end{array}$ \\
\hline 80 & 100.00 & 100.00 & 100.00 & 100.00 & 100.00 & 100.00 & 100.00 \\
\hline 79 & 98.84 & 99.05 & 99.29 & 98.80 & 98.21 & 98.56 & 97.87 \\
\hline 78 & 98.75 & 98.93 & 99.29 & 98.57 & 98.21 & 98.56 & 97.87 \\
\hline 77 & 97.86 & 98.21 & 98.81 & 97.61 & 96.79 & 98.56 & 95.04 \\
\hline 76 & 97.14 & 97.74 & 98.81 & 96.65 & 95.36 & 97.12 & 93.62 \\
\hline 75 & 95.89 & 96.90 & 97.63 & 96.17 & 92.86 & 94.96 & 90.78 \\
\hline 74 & 94.91 & 96.31 & 97.15 & 95.46 & 90.71 & 92.81 & 88.65 \\
\hline 73 & 94.19 & 95.83 & 97.15 & 94.50 & 89.29 & 91.37 & 87.23 \\
\hline 72 & 93.66 & 95.71 & 97.15 & 94.26 & 87.50 & 90.65 & 84.40 \\
\hline 71 & 93.30 & 95.59 & 97.15 & 94.02 & 86.43 & 89.93 & 82.98 \\
\hline 70 & 92.67 & 94.99 & 96.68 & 93.30 & 85.71 & 89.21 & 82.27 \\
\hline 69 & 91.60 & 94.28 & 95.96 & 92.58 & 83.57 & 87.77 & 79.43 \\
\hline 68 & 90.53 & 93.21 & 94.54 & 91.87 & 82.50 & 87.05 & 78.01 \\
\hline 67 & 89.54 & 92.61 & 93.82 & 91.39 & 80.36 & 84.89 & 75.89 \\
\hline 66 & 87.85 & 91.18 & 93.11 & 89.23 & 77.86 & 82.73 & 73.05 \\
\hline 65 & 86.33 & 89.63 & 92.16 & 87.08 & 76.43 & 81.30 & 71.63 \\
\hline 64 & 83.74 & 87.37 & 90.26 & 84.45 & 72.86 & 76.98 & 68.79 \\
\hline 63 & 79.45 & 83.31 & 86.22 & 80.38 & 67.86 & 71.94 & 63.83 \\
\hline 62 & 76.32 & 80.57 & 84.32 & 76.79 & 63.57 & 68.35 & 58.87 \\
\hline 61 & 73.82 & 77.95 & 82.66 & 73.21 & 61.43 & 67.63 & 55.32 \\
\hline 60 & 71.40 & 76.04 & 80.76 & 71.29 & 57.50 & 63.31 & 51.77 \\
\hline 59 & 68.28 & 73.78 & 78.15 & 69.38 & 51.79 & 59.71 & 43.97 \\
\hline 58 & 65.59 & 71.16 & 74.58 & 67.70 & 48.93 & 56.84 & 41.14 \\
\hline 57 & 62.47 & 67.70 & 70.55 & 64.83 & 46.79 & 53.24 & 40.43 \\
\hline 56 & 58.45 & 63.77 & 66.51 & 61.01 & 42.50 & 48.92 & 36.17 \\
\hline 55 & 55.76 & 60.91 & 63.18 & 58.61 & 40.36 & 46.04 & 34.75 \\
\hline 54 & 52.19 & 57.33 & 60.33 & 54.31 & 36.79 & 42.45 & 31.21 \\
\hline 53 & 48.62 & 53.64 & 56.30 & 50.96 & 33.57 & 39.57 & 27.66 \\
\hline 52 & 46.02 & 50.78 & 54.63 & 46.89 & 31.79 & 37.41 & 26.24 \\
\hline 51 & 42.90 & 47.20 & 50.83 & 43.54 & 30.00 & 35.25 & 24.82 \\
\hline 50 & 39.68 & 43.98 & 47.74 & 40.19 & 26.79 & 32.37 & 21.28 \\
\hline 49 & 35.21 & 39.21 & 42.04 & 36.36 & 23.21 & 28.78 & 17.73 \\
\hline 48 & 32.62 & 36.35 & 39.67 & 33.01 & 21.43 & 25.90 & 17.02 \\
\hline 47 & 22.97 & 25.51 & 27.79 & 23.21 & 15.36 & 20.86 & 9.93 \\
\hline
\end{tabular}


Table A

Table A continued

\begin{tabular}{|c|c|c|c|c|c|c|c|}
\hline \multirow{2}{*}{$\begin{array}{l}\text { VoSQ } \\
\text { general } \\
\text { scores }\end{array}$} & \multicolumn{7}{|c|}{ Cumulated frequencies of scores } \\
\hline & All & $\begin{array}{c}18-64 \\
\text { All }\end{array}$ & $\begin{array}{c}18-64 \\
\text { Female }\end{array}$ & $\begin{array}{l}18-64 \\
\text { Male }\end{array}$ & $\begin{array}{r}65+ \\
\text { All } \\
\end{array}$ & $\begin{array}{c}65+ \\
\text { Female } \\
\end{array}$ & $\begin{array}{c}65+ \\
\text { Male } \\
\end{array}$ \\
\hline 46 & 21.18 & 23.24 & 25.42 & 21.05 & 15.00 & 20.14 & 9.93 \\
\hline 45 & 18.95 & 20.62 & 22.57 & 18.66 & 13.93 & 17.99 & 9.93 \\
\hline 44 & 17.25 & 19.07 & 20.67 & 17.46 & 11.79 & 15.11 & 8.51 \\
\hline 43 & 15.10 & 16.69 & 18.53 & 14.83 & 10.36 & 12.23 & 8.51 \\
\hline 42 & 13.23 & 14.66 & 16.63 & 12.68 & 8.93 & 10.79 & 7.09 \\
\hline 41 & 11.71 & 12.75 & 14.49 & 11.01 & 8.57 & 10.07 & 7.09 \\
\hline 40 & 10.46 & 11.56 & 13.30 & 9.81 & 7.14 & 7.91 & 6.38 \\
\hline 39 & 9.47 & 10.37 & 11.40 & 9.33 & 6.79 & 7.91 & 5.67 \\
\hline 38 & 7.86 & 9.18 & 9.74 & 8.61 & 3.93 & 3.60 & 4.26 \\
\hline 37 & 7.24 & 8.46 & 8.79 & 8.13 & 3.57 & 3.60 & 3.55 \\
\hline 36 & 6.52 & 7.87 & 8.31 & 7.42 & 2.50 & 2.16 & 2.84 \\
\hline 35 & 5.81 & 7.03 & 7.60 & 6.46 & 2.14 & 2.16 & 2.13 \\
\hline 34 & 5.27 & 6.32 & 6.65 & 5.98 & 2.14 & 2.16 & 2.13 \\
\hline 33 & 5.09 & 6.08 & 6.18 & 5.98 & 2.14 & 2.16 & 2.13 \\
\hline 32 & 4.83 & 5.72 & 6.18 & 5.26 & 2.14 & 2.16 & 2.13 \\
\hline 31 & 4.02 & 4.65 & 5.70 & 3.59 & 2.14 & 2.16 & 2.13 \\
\hline 30 & 3.58 & 4.17 & 5.46 & 2.87 & 1.79 & 1.44 & 2.13 \\
\hline 29 & 3.13 & 3.70 & 4.75 & 2.63 & 1.43 & 0.72 & 2.13 \\
\hline 28 & 2.68 & 3.22 & 3.80 & 2.63 & 1.07 & 0.72 & 1.42 \\
\hline 27 & 2.41 & 2.98 & 3.56 & 2.39 & 0.71 & 0.72 & 0.71 \\
\hline 26 & 2.32 & 2.86 & 3.33 & 2.39 & 0.71 & 0.72 & 0.71 \\
\hline 25 & 1.97 & 2.38 & 2.38 & 2.39 & 0.71 & 0.72 & 0.71 \\
\hline 24 & 1.70 & 2.15 & 2.14 & 2.15 & 0.36 & 0.72 & 0.00 \\
\hline 23 & 1.43 & 1.79 & 1.90 & 1.68 & 0.36 & 0.72 & 0.00 \\
\hline 22 & 1.34 & 1.67 & 1.90 & 1.44 & 0.36 & 0.72 & 0.00 \\
\hline 21 & 1.07 & 1.43 & 1.66 & 1.20 & 0.00 & 0.00 & 0.00 \\
\hline 20 & 0.98 & 1.31 & 1.66 & 0.96 & 0.00 & 0.00 & 0.00 \\
\hline 19 & 0.80 & 1.07 & 1.19 & 0.96 & 0.00 & 0.00 & 0.00 \\
\hline 18 & 0.72 & 0.95 & 0.95 & 0.96 & 0.00 & 0.00 & 0.00 \\
\hline 17 & 0.54 & 0.72 & 0.48 & 0.96 & 0.00 & 0.00 & 0.00 \\
\hline 16 & 0.45 & 0.60 & 0.24 & 0.96 & 0.00 & 0.00 & 0.00 \\
\hline
\end{tabular}


Table B

Cumulative frequencies of scores of Views of Science Questionnaire subscales

\begin{tabular}{|c|c|c|c|c|c|c|c|}
\hline \multirow{2}{*}{$\begin{array}{l}\text { Trust in Scientific } \\
\text { Method scores }\end{array}$} & \multicolumn{7}{|c|}{ Cumulated frequencies of scores } \\
\hline & All & $\begin{array}{c}18-64 \\
\text { AlI }\end{array}$ & $\begin{array}{c}18-64 \\
\text { Female }\end{array}$ & $\begin{array}{l}18-64 \\
\text { Male }\end{array}$ & $\begin{array}{l}65+ \\
\text { All }\end{array}$ & $\begin{array}{c}65+ \\
\text { Female }\end{array}$ & $\begin{array}{c}65+ \\
\text { Male }\end{array}$ \\
\hline 20 & 100.00 & 100.00 & 100.00 & 100.00 & 100.00 & 100.00 & 100.00 \\
\hline 19 & 95.62 & 97.02 & 98.10 & 95.93 & 91.43 & 90.65 & 92.20 \\
\hline 18 & 92.14 & 94.64 & 96.20 & 93.06 & 84.64 & 85.61 & 83.69 \\
\hline 17 & 87.40 & 90.70 & 93.35 & 88.04 & 77.50 & 82.01 & 73.05 \\
\hline 16 & 80.34 & 84.63 & 87.89 & 81.34 & 67.50 & 70.50 & 64.54 \\
\hline 15 & 67.47 & 72.59 & 74.82 & 70.34 & 52.14 & 56.84 & 47.52 \\
\hline 14 & 56.93 & 61.98 & 64.37 & 59.57 & 41.79 & 43.89 & 39.72 \\
\hline 13 & 44.42 & 49.70 & 51.78 & 47.61 & 28.57 & 30.22 & 26.95 \\
\hline 12 & 31.73 & 36.47 & 38.24 & 34.69 & 17.50 & 15.83 & 19.15 \\
\hline 11 & 15.28 & 17.88 & 18.77 & 16.99 & 7.50 & 5.76 & 9.22 \\
\hline 10 & 10.10 & 12.04 & 12.35 & 11.72 & 4.29 & 4.32 & 4.26 \\
\hline 9 & 6.35 & 7.75 & 6.89 & 8.61 & 2.14 & 2.16 & 2.13 \\
\hline 8 & 4.47 & 5.48 & 4.28 & 6.70 & 1.43 & 0.72 & 2.13 \\
\hline 7 & 2.59 & 3.22 & 3.09 & 3.35 & 0.71 & 0.72 & 0.71 \\
\hline 6 & 1.70 & 2.27 & 2.14 & 2.39 & 0.00 & 0.00 & 0.00 \\
\hline 5 & 1.07 & 1.43 & 1.19 & 1.68 & 0.00 & 0.00 & 0.00 \\
\hline 4 & 0.80 & 1.07 & 0.95 & 1.20 & 0.00 & 0.00 & 0.00 \\
\hline \multirow{2}{*}{$\begin{array}{l}\text { Scientists } \\
\text { as the Only } \\
\text { Experts scores }\end{array}$} & \multicolumn{7}{|c|}{ Cumulated frequencies of scores } \\
\hline & All & $\begin{array}{c}18-64 \\
\text { All }\end{array}$ & $\begin{array}{c}18-64 \\
\text { Female }\end{array}$ & $\begin{array}{l}18-64 \\
\text { Male }\end{array}$ & $\begin{array}{r}65+ \\
\text { All } \\
\end{array}$ & $\begin{array}{c}65+ \\
\text { Female }\end{array}$ & $\begin{array}{c}65+ \\
\text { Male } \\
\end{array}$ \\
\hline 20 & 100.00 & 100.00 & 100.00 & 100.00 & 100.00 & 100.00 & 100.00 \\
\hline 19 & 93.03 & 94.76 & 96.20 & 93.30 & 87.86 & 92.09 & 83.69 \\
\hline 18 & 89.01 & 91.54 & 94.06 & 89.00 & 81.43 & 84.89 & 78.01 \\
\hline 17 & 83.83 & 87.25 & 90.97 & 83.49 & 73.57 & 79.86 & 67.38 \\
\hline 16 & 76.32 & 81.05 & 84.09 & 77.99 & 62.14 & 69.07 & 55.32 \\
\hline 15 & 63.72 & 68.65 & 73.40 & 63.88 & 48.93 & 57.55 & 40.43 \\
\hline 14 & 55.05 & 59.95 & 65.56 & 54.31 & 40.36 & 48.92 & 31.92 \\
\hline 13 & 45.93 & 50.89 & 55.82 & 45.93 & 31.07 & 38.13 & 24.11 \\
\hline 12 & 35.66 & 39.69 & 43.47 & 35.89 & 23.57 & 28.06 & 19.15 \\
\hline 11 & 19.04 & 20.98 & 25.65 & 16.27 & 13.21 & 16.55 & 9.93 \\
\hline 10 & 13.76 & 15.50 & 18.29 & 12.68 & 8.57 & 10.79 & 6.38 \\
\hline 9 & 10.01 & 11.20 & 12.35 & 10.05 & 6.43 & 7.91 & 4.97 \\
\hline 8 & 8.13 & 9.06 & 9.74 & 8.37 & 5.36 & 5.76 & 4.97 \\
\hline 7 & 4.65 & 5.48 & 6.18 & 4.79 & 2.14 & 2.88 & 1.42 \\
\hline 6 & 3.22 & 3.81 & 4.28 & 3.35 & 1.43 & 1.44 & 1.42 \\
\hline 5 & 2.32 & 2.74 & 3.33 & 2.15 & 1.07 & 0.72 & 1.42 \\
\hline 4 & 1.70 & 2.03 & 2.61 & 1.44 & 0.71 & 0.72 & 0.71 \\
\hline
\end{tabular}


Table B

Table B continued

\begin{tabular}{|c|c|c|c|c|c|c|c|}
\hline \multirow{2}{*}{$\begin{array}{l}\text { Science } \\
\text { as a Source } \\
\text { of Hope scores }\end{array}$} & \multicolumn{7}{|c|}{ Cumulated frequencies of scores } \\
\hline & All & $\begin{array}{c}18-64 \\
\text { All }\end{array}$ & $\begin{array}{c}18-64 \\
\text { Female }\end{array}$ & $\begin{array}{l}18-64 \\
\text { Male }\end{array}$ & $\begin{array}{l}65+ \\
\text { All }\end{array}$ & $\begin{array}{c}65+ \\
\text { Female }\end{array}$ & $\begin{array}{c}65+ \\
\text { Male }\end{array}$ \\
\hline 20 & 100.00 & 100.00 & 100.00 & 100.00 & 100.00 & 100.00 & 100.00 \\
\hline 19 & 97.50 & 97.74 & 98.81 & 96.65 & 96.79 & 97.12 & 96.45 \\
\hline 18 & 95.09 & 96.54 & 97.39 & 95.69 & 90.71 & 94.25 & 87.23 \\
\hline 17 & 92.58 & 94.52 & 96.44 & 92.58 & 86.79 & 92.09 & 81.56 \\
\hline 16 & 87.67 & 90.47 & 93.11 & 87.80 & 79.29 & 83.45 & 75.18 \\
\hline 15 & 77.39 & 79.26 & 81.95 & 76.56 & 71.79 & 75.54 & 68.09 \\
\hline 14 & 68.10 & 70.20 & 73.87 & 66.51 & 61.79 & 67.63 & 56.03 \\
\hline 13 & 56.39 & 60.55 & 64.37 & 56.70 & 43.93 & 51.08 & 36.88 \\
\hline 12 & 44.24 & 47.68 & 50.83 & 44.50 & 33.93 & 40.29 & 27.66 \\
\hline 11 & 26.54 & 27.89 & 29.45 & 26.32 & 22.50 & 28.06 & 17.02 \\
\hline 10 & 18.68 & 19.67 & 20.90 & 18.42 & 15.71 & 20.86 & 10.64 \\
\hline 9 & 12.24 & 13.11 & 14.25 & 11.96 & 9.64 & 13.67 & 5.67 \\
\hline 8 & 7.69 & 7.87 & 8.08 & 7.66 & 7.14 & 10.07 & 4.26 \\
\hline 7 & 5.18 & 5.72 & 6.18 & 5.26 & 3.57 & 4.32 & 2.84 \\
\hline 6 & 3.75 & 4.77 & 4.75 & 4.79 & 0.71 & 1.44 & 0.00 \\
\hline 5 & 2.41 & 3.22 & 3.56 & 2.87 & 0.00 & 0.00 & 0.00 \\
\hline 4 & 1.43 & 1.91 & 2.38 & 1.44 & 0.00 & 0.00 & 0.00 \\
\hline \multirow{2}{*}{$\begin{array}{l}\text { Science as a Tool } \\
\text { of Practical } \\
\text { Influence scores }\end{array}$} & \multicolumn{7}{|c|}{ Cumulated frequencies of scores } \\
\hline & All & $\begin{array}{c}18-64 \\
\text { All } \\
\end{array}$ & $\begin{array}{c}18-64 \\
\text { Female }\end{array}$ & $\begin{array}{l}18-64 \\
\text { Male }\end{array}$ & $\begin{array}{l}65+ \\
\text { All } \\
\end{array}$ & $\begin{array}{c}65+ \\
\text { Female } \\
\end{array}$ & $\begin{array}{c}65+ \\
\text { Male } \\
\end{array}$ \\
\hline 20 & 100.00 & 100.00 & 100.00 & 100.00 & 100.00 & 100.00 & 100.00 \\
\hline 19 & 96.96 & 97.38 & 97.39 & 97.37 & 95.71 & 96.40 & 95.04 \\
\hline 18 & 95.26 & 96.54 & 96.44 & 96.65 & 91.43 & 93.53 & 89.36 \\
\hline 17 & 92.23 & 94.76 & 95.49 & 94.02 & 84.64 & 89.93 & 79.43 \\
\hline 16 & 88.03 & 91.42 & 92.64 & 90.19 & 77.86 & 83.45 & 72.34 \\
\hline 15 & 76.50 & 79.98 & 81.47 & 78.47 & 66.07 & 71.94 & 60.28 \\
\hline 14 & 67.92 & 71.40 & 74.58 & 68.18 & 57.50 & 61.15 & 53.90 \\
\hline 13 & 55.94 & 59.48 & 63.42 & 55.50 & 45.36 & 49.64 & 41.14 \\
\hline 12 & 45.58 & 48.87 & 50.83 & 46.89 & 35.71 & 39.57 & 31.92 \\
\hline 11 & 27.79 & 30.04 & 31.83 & 28.23 & 21.07 & 22.30 & 19.86 \\
\hline 10 & 19.93 & 21.93 & 23.99 & 19.86 & 13.93 & 17.27 & 10.64 \\
\hline 9 & 15.37 & 17.16 & 18.29 & 16.03 & 10.00 & 10.79 & 9.22 \\
\hline 8 & 10.55 & 11.80 & 12.11 & 11.48 & 6.79 & 6.48 & 7.09 \\
\hline 7 & 6.70 & 7.63 & 7.60 & 7.66 & 3.93 & 5.76 & 2.13 \\
\hline 6 & 4.11 & 4.41 & 4.51 & 4.31 & 3.21 & 4.32 & 2.13 \\
\hline 5 & 2.77 & 2.98 & 3.56 & 2.39 & 2.14 & 2.88 & 1.42 \\
\hline 4 & 1.34 & 1.67 & 1.90 & 1.44 & 0.36 & 0.72 & 0.00 \\
\hline
\end{tabular}


Table C

Qualitative interpretation of Views of Science Questionnaire subscale scores

\begin{tabular}{|c|c|c|c|c|c|c|c|c|}
\hline \multirow[t]{2}{*}{ Percentiles } & \multirow[t]{2}{*}{ Interpretation } & \multicolumn{7}{|c|}{ Trust in Scientific Method score } \\
\hline & & All & $\begin{array}{c}18-64 \\
\text { All }\end{array}$ & $\begin{array}{c}18-64 \\
\text { Female }\end{array}$ & $\begin{array}{l}18-64 \\
\text { Male }\end{array}$ & $\begin{array}{c}65+ \\
\text { All }\end{array}$ & $\begin{array}{c}65+ \\
\text { Female }\end{array}$ & $\begin{array}{c}65+ \\
\text { Male }\end{array}$ \\
\hline$\leq 99$ & Very high & 20 & 20 & $19-20$ & 20 & 20 & 20 & 20 \\
\hline $90-98$ & High & $18-19$ & $17-19$ & $17-18$ & $18-19$ & 19 & 19 & 19 \\
\hline $76-89$ & Above average & $16-17$ & 16 & 16 & $16-17$ & $17-18$ & $17-18$ & 18 \\
\hline $25-75$ & Average & $12-15$ & $12-15$ & $12-15$ & $12-15$ & $13-16$ & $13-16$ & $13-17$ \\
\hline $11-24$ & Below average & $10-11$ & $10-11$ & $10-11$ & $10-11$ & 12 & 12 & 12 \\
\hline $3-10$ & Low & $7-9$ & $6-9$ & $6-9$ & $6-9$ & $9-11$ & $9-11$ & $8-11$ \\
\hline$\leq 2$ & Very low & $4-6$ & $4-5$ & $4-5$ & $4-5$ & $4-8$ & $4-8$ & $4-7$ \\
\hline \multirow[t]{2}{*}{ Percentiles } & \multirow[t]{2}{*}{ Interpretation } & \multicolumn{7}{|c|}{ Scientists as the Only Experts score } \\
\hline & & All & $\begin{array}{c}18-64 \\
\text { All }\end{array}$ & $\begin{array}{c}18-64 \\
\text { Female }\end{array}$ & $\begin{array}{l}18-64 \\
\text { Male }\end{array}$ & $\begin{array}{c}65+ \\
\text { All }\end{array}$ & $\begin{array}{c}65+ \\
\text { Female }\end{array}$ & $\begin{array}{c}65+ \\
\text { Male }\end{array}$ \\
\hline$\leq 99$ & Very high & 20 & 20 & 20 & 20 & - & 20 & - \\
\hline $90-98$ & High & 19 & $18-19$ & $17-19$ & 19 & 20 & 19 & 20 \\
\hline $76-89$ & Above average & $16-18$ & $16-17$ & 16 & $16-18$ & $18-19$ & $17-18$ & $18-19$ \\
\hline $25-75$ & Average & $12-15$ & $12-15$ & $11-15$ & $12-15$ & $13-17$ & $12-16$ & $14-17$ \\
\hline $11-24$ & Below average & $9-11$ & $9-11$ & $9-10$ & $9-11$ & $11-12$ & $10-11$ & $12-13$ \\
\hline $3-10$ & Low & $5-8$ & $4-8$ & $4-8$ & $5-8$ & $7-10$ & $7-9$ & $8-11$ \\
\hline$\leq 2$ & Very low & 4 & - & - & 4 & $4-6$ & $4-6$ & $4-7$ \\
\hline \multirow[t]{2}{*}{ Percentiles } & \multirow[t]{2}{*}{ Interpretation } & \multicolumn{7}{|c|}{ Science as a Source of Hope score } \\
\hline & & All & $\begin{array}{c}18-64 \\
\text { All }\end{array}$ & $\begin{array}{c}18-64 \\
\text { Female } \\
\end{array}$ & $\begin{array}{l}18-64 \\
\text { Male }\end{array}$ & $\begin{array}{r}65+ \\
\text { All } \\
\end{array}$ & $\begin{array}{c}65+ \\
\text { Female } \\
\end{array}$ & $\begin{array}{c}65+ \\
\text { Male } \\
\end{array}$ \\
\hline$\leq 99$ & Very high & 20 & 20 & $19-20$ & 20 & 20 & 20 & 20 \\
\hline $90-98$ & High & $17-19$ & $16-19$ & $16-18$ & $17-19$ & $18-19$ & $17-19$ & 19 \\
\hline $76-89$ & Above average & $15-16$ & 15 & 15 & $15-16$ & $16-17$ & $15-16$ & $16-18$ \\
\hline $25-75$ & Average & $11-14$ & $11-14$ & $11-16$ & $11-14$ & $12-15$ & $11-14$ & $12-15$ \\
\hline $11-24$ & Below average & $9-10$ & $9-10$ & $9-10$ & $9-10$ & $10-11$ & $8-10$ & $10-11$ \\
\hline $3-10$ & Low & $5-8$ & $5-8$ & $4-8$ & $5-8$ & $7-9$ & 7 & $7-9$ \\
\hline$\leq 2$ & Very low & 4 & 4 & - & 4 & $4-6$ & $4-6$ & $4-6$ \\
\hline \multirow[t]{2}{*}{ Percentiles } & \multirow[t]{2}{*}{ Interpretation } & \multicolumn{7}{|c|}{ Science as a Tool of Practical Influence score } \\
\hline & & All & $\begin{array}{c}18-64 \\
\text { All }\end{array}$ & $\begin{array}{c}18-64 \\
\text { Female }\end{array}$ & $\begin{array}{l}18-64 \\
\text { Male }\end{array}$ & $\begin{array}{c}65+ \\
\text { All }\end{array}$ & $\begin{array}{c}65+ \\
\text { Female }\end{array}$ & $\begin{array}{c}65+ \\
\text { Male }\end{array}$ \\
\hline$\leq 99$ & Very high & 20 & 20 & 20 & 20 & 20 & 20 & 20 \\
\hline $90-98$ & High & $17-19$ & $16-19$ & $16-19$ & $16-19$ & $18-19$ & $18-19$ & 19 \\
\hline $76-89$ & Above average & $15-16$ & 15 & 15 & 15 & $16-17$ & $16-17$ & $17-18$ \\
\hline $25-75$ & Average & $11-14$ & $11-14$ & $11-14$ & $11-14$ & $12-15$ & $12-15$ & $12-16$ \\
\hline $11-24$ & Below average & $8-10$ & $8-10$ & $8-10$ & $8-10$ & $9-11$ & $9-11$ & $10-11$ \\
\hline $3-10$ & Low & $5-7$ & $5-7$ & $5-7$ & $5-7$ & $5-8$ & $5-8$ & $6-9$ \\
\hline$\leq 2$ & Very low & 4 & 4 & 4 & 4 & 4 & 4 & $4-5$ \\
\hline
\end{tabular}

